\title{
Diallyl disulfide induces downregulation and inactivation of cofilin 1 differentiation via the Rac1/ROCK1/LIMK1 pathway in leukemia cells
}

\author{
HUI LING ${ }^{1,2^{*}}$, XIAOXIA JI ${ }^{1,3^{*}}$, YANPING LEI ${ }^{1,4^{*}}$, YANHONG JIA ${ }^{1,5}$, FANG LIU ${ }^{1,2}$, HONG

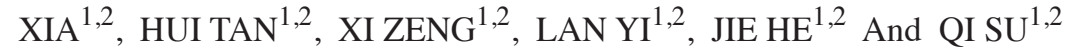 \\ ${ }^{1}$ Key Laboratory of Tumor Cellular and Molecular Pathology (University of South China), \\ College of Hunan Province, Cancer Research Institute, Hengyang Medical College; \\ ${ }^{2}$ Hunan Province Cooperative Innovation Center for Molecular Target New Drug Study, University of South China, \\ Hengyang, Hunan 421001; ${ }^{3}$ Department of Pathology, Yun Cheng Central Hospital, Yuncheng, Shanxi 044000; \\ ${ }^{4}$ Department of Pathophysiology, Hengyang Medical College, University of South China, Hengyang, \\ Hunan 421001; ${ }^{5}$ Department of Pathology, Space Flight General Hospital, Xi'an, Shanxi 710025, P.R. China
}

Received July 5, 2019; Accepted January 2, 2020

DOI: 10.3892/ijo.2020.4968

\begin{abstract}
Cofilin is associated with cell differentiation; however, to the best of our knowledge, no data have indicated an association between the cofilin 1 pathway and leukemia cell differentiation. The present study investigated the involvement of the cofilin 1 signaling pathway in diallyl disulfide (DADS)-induced differentiation and the inhibitory effects on the proliferation, migration, and invasion of human leukemia HL-60 cells. First, it was identified that $8 \mu \mathrm{M}$ DADS suppressed cell proliferation, migration and invasion, and induced differentiation based on the reduced nitroblue tetrazolium ability and increased CD11b and CD33 expression. DADS significantly downregulated the expression of cofilin 1 and phosphorylated cofilin 1 in HL-60 leukemia cells. Second, it was verified that silencing cofilin 1 markedly promoted $8 \mu \mathrm{M}$ DADS-induced differentiation and the inhibitory effect
\end{abstract}

Correspondence to: Ms. Jie He or Professor Qi Su, Key Laboratory of Tumor Cellular and Molecular Pathology (University of South China), College of Hunan Province, Cancer Research Institute, Hengyang Medical College, University of South China, 28 Changsheng Xi Road, Hengyang, Hunan 421001, P.R. China E-mail: $2601205183 @ q q . c o m$

E-mail: suqi1945@163.com

*Contributed equally

Abbreviations: DADS, diallyl disulfide; NBT, nitroblue tetrazolium; BCA, bicinchoninic acid; ROCK1, Rho-associated protein kinase 1; RT-semi-qPCR, reverse transcription-semi-quantitative polymerase chain reaction; OD, optical density; ATRA, all-trans retinoic acid; ADF, actin depolymerizing factor; LIMK1, LIM domain kinase 1

Key words: leukemia, diallyl disulfide, cofilin 1, differentiation, proliferation on cell proliferation and invasion. Overexpression of cofilin 1 obviously suppressed $8 \mu \mathrm{M}$ DADS-induced differentiation and the inhibitory effect on cell proliferation and invasion. Third, the present study examined the mechanisms by which 8 $\mu \mathrm{M}$ DADS decreases cofilin 1 expression and activation. The results revealed that $8 \mu \mathrm{M}$ DADS inhibited the mRNA and protein expression of Rac1, Rho-associated protein kinase 1 (ROCK1) and LIM domain kinase 1 (LIMK1) as well as the phosphorylation of LIMK1 in HL-60 cells, while $8 \mu$ M DADS enhanced the effects of the Rac1-ROCK1-LIMK1 pathway in cells overexpressing cofilin 1 compared with that in control HL-60 cells. These results suggest that the anticancer function of DADS on HL-60 leukemia cells is regulated by the Rac1-ROCK1-LIMK1-cofilin 1 pathway, indicating that DADS could be a promising anti-leukemia therapeutic compound.

\section{Introduction}

Acute myeloid leukemia (AML) is a malignant and aggressive disease that is sensitive to chemotherapy (1). Although current therapeutic strategies provide a reasonable likelihood of achieving complete remission for the majority of patients, the relapse rates and subsequent disease-associated mortality remain unacceptably high $(1,2)$. There were an estimated 21,450 newly diagnosed cases of AML and 10,920 AML-associated mortalities in the USA in 2019 (2). Improvements in chemotherapeutic regimens and supportive care have increased overall survival rates in younger patients ( $<15$ years of age) to $>60 \%$; however, $40 \%$ ultimately relapse and require salvage therapy (1). Therefore, there is an urgent need to develop a novel therapeutic drug to enhance chemosensitization. Diallyl disulfide (DADS), a major oil-soluble compound derived from garlic, has multi-targeted antitumor activities in diverse cancer types, which results in the induction of cellular processes, including cell cycle arrest, growth inhibition, differentiation and apoptosis (3). Our previous study (4) demonstrated that DADS could induce 
the differentiation and inhibit the growth of HL-60 cells by increasing the expression of acetylated histone $\mathrm{H} 3, \mathrm{H} 4$ and p21WAF1 in vitro and in vivo. Using high-resolution mass spectrometry, a total of 18 differentially expressed proteins were identified after treatment with DADS, including four upregulated and fourteen downregulated proteins, among which the protein expression of cofilin 1 was downregulated (5).

Cofilin is an actin-binding protein universally present in eukaryotes that has a molecular weight of $21 \mathrm{kD}$ (6). Two mammalian cofilin gene subtypes exist, cofilin 1 and cofilin 2 , which encode different proteins. The former is expressed in a variety of tissues except muscle, and the latter is mainly expressed in muscle tissue $(7,8)$. Cofilin can depolymerize actin filaments and regulate the cytoskeleton (9). A basic function of cofilin is to combine with and depolymerize F-actin intracellularly, thereby inhibiting G-actin polymerization and accelerating actin filament dynamic transformation (10). At the same time, cofilin plays an important role in regulating cell movement (11). The cofilin 1 pathway is regarded as a target to suppress the growth of breast cancer cells (12) and also serves an important role in inhibiting epithelial mesenchymal transition in gastric adenocarcinoma cells (13).

Cofilin can be acted upon by two types of kinases, LIM kinases (LIMKs) and testicular protein kinases, which induce cofilin phosphorylation at the Ser3 site, inhibit the binding of cofilin to F-actin and stabilize F-actin. Two types of cofilin dephosphorylate, Slingshot and chronophin, which can dephosphorylate cofilin, thereby causing the depolymerization and removal of F-actin, promoting actin nucleation through Arp 2/3 and inducing other actin polymerization events and directional movement (14). Cofilin 1 helps regulate glioblastoma cell migration by modulating the cytoskeleton via multiple targets, including F-actin regulation and RhoGTPase activity, such as small Rho-GTPases RhoA and Rac1 activity (15). LIMK1 positively controls the expression and phosphorylation of cofilin 1 , leading to rearrangement of the cellular actin cytoskeleton, which serves roles in the growth and motility inhibition of breast cancer cells (12).

Cofilin is associated with cell differentiation in vivo and outside factors can control cofilin through relative cell signaling pathways, thus regulating the actin cytoskeleton to induce differentiation (16). Despite this information, no data have indicated an association between the cofilin 1 pathway and leukemia cell differentiation. The present study aimed to clarify whether downregulation and inactivation of cofilin 1 by DADS induces differentiation. In addition, the mechanism underlying the inhibitory effects on the proliferation, migration and invasion of human leukemia HL-60 cells, and the mechanisms by which DADS mediates cofilin 1 downregulation and inactivation were investigated.

\section{Materials and methods}

Reagents. DADS was obtained from Sigma-Aldrich; Merck KGaA. DADS was dissolved in $0.1 \%$ Tween- 80 (catalog no. E7034; Sigma-Aldrich) at $8 \mathrm{~g} / 1$ and stored at $-20^{\circ} \mathrm{C}$. Matrigel was obtained from BD Biosciences. Transwell chambers $(8-\mu \mathrm{m})$ were provided by Corning, Inc. CCK-8 was obtained from Dojindo Molecular Technologies, Inc. The total RNA kit II (catalog no. R6934) was purchased from
Omega Biotek, Inc., the PrimeScript ${ }^{\mathrm{TM}}$ RT reagent kit (catalog no. RR037A) was purchased from Takara Bio, Inc., the PCR Optimization kit (catalog no. D2381) was purchased from Promega Corporation, and the BeyoECL Plus Hypersensitive ECL Chemiluminescence kit (catalog no. P0018S), BCA Protein assay kit (catalog no. P0012) and the $\beta$-actin mouse monoclonal antibody (catalog no. AF5001) were purchased from Beyotime Institute of Biotechnology. Nitrotetrazolium Blue chloride (NBT; catalog no. N6876) was purchased from Sigma-Aldrich; Merck KGaA. The primary antibodies against LIMK1 (catalog no. BS2016), phosphorylated (p)-LIMK1 (catalog no. BS4115) and p-cofilin 1 (catalog no. BS4716) were purchased from Bioword Technology, Inc. The primary antibody against Rac1 (catalog no. 10485-2-AP), horseradish peroxidase-conjugated affinipure goat anti-mouse IgG $(\mathrm{H}+\mathrm{L})$ secondary antibody (catalog no. SA00001-1) and horseradish peroxidase-conjugated affinipure goat anti-Rabbit IgG $(\mathrm{H}+\mathrm{L})$ secondary antibody (catalog no. SA00001-2) were purchased from ProteinTech Group, Inc. The primary antibodies against cofilin 1 (catalog no. S2056), Rho-associated protein kinase 1 (ROCK1; catalog no. 1953-1), CD11b (catalog no. 1936-1) and CD33 (catalog no. 3807-1) were provided by Epitomics; Abcam. The cofilin 1 high expression vector (pcDNA3.1-cofilin 1-IRES2-EGFP eukaryotic expression plasmid), empty vector pcDNA3.1 (control), cofilin 1 knockdown vector [pcDNA ${ }^{\mathrm{TM}} 6.2-\mathrm{GW} / \mathrm{EmGFPmiR}$ cofilin 1-microRNA (miRNA)-expressing plasmid) and empty vector pcDNA ${ }^{\mathrm{TM}} 6.2$ (control) were constructed by Invitrogen; Thermo Fisher Scientific, Inc.

Cell culture and establishment of cells lines stably overexpressing and silencing cofilin 1. The human leukemia cell line HL-60 was obtained from the Cancer Research Institute, Xiangya Medical College, Central South University, Changsha, China. Cells were maintained in RPMI-1640 complete medium (Gibco; Thermo Fisher Scientific, Inc.) containing $10 \%$ fetal bovine serum (catalog no. 11011-8611; Tianhang of Sijiqing Hangzhou Technologies), $100 \mathrm{U} / \mathrm{ml}$ penicillin and $100 \mathrm{U} / \mathrm{ml}$ streptomycin in a humidified incubator at $37^{\circ} \mathrm{C}$ and $5 \% \mathrm{CO}_{2}$. Cells were transfected with $0.12 \mu \mathrm{g} / 1$ pcDNA3.1-cofilin 1-IRES2-EGFP eukaryotic expression plasmid to overexpress cofilin, $0.12 \mu \mathrm{g} / 1$ empty vector pcDNA3.1 (control), $0.05 \mu \mathrm{g} / 1 \mathrm{pcDNA}^{\mathrm{TM}} 6.2-\mathrm{GW} / \mathrm{EmGFPmiR}$ cofilin 1-microRNA (miRNA)-expressing plasmid to knockdown cofilin 1 and $0.05 \mu \mathrm{g} / 1$ empty vector pcDNA $^{\mathrm{TM}} 6.2$ (control) using Attractene Transfection Reagent (catalog no. 301005; Qiangen $\mathrm{GmbH}$ ) to generate a HL-60 cell line stably overexpressing cofilin 1 and a cell line in which cofilin 1 was silenced (termed cofilin-miR). G418 (catalog no. 10131035; Gibco; Thermo Fisher Scientific, Inc.) was used to screen positive cell clones. After screening for 10-14 days, the concentration of G418 was halved to maintain the screening, and was used in experiments after cell proliferation. Reverse transcription-semi-quantitative PCR (RT-semi-qPCR) and western blotting were performed to confirm the establishment of cofilin 1 stably overexpressing and silenced cell lines after transfection for $48 \mathrm{~h}$.

Cell proliferation analysis. The effect of DADS or cofilin 1 on HL-60 cell proliferation was measured using the CCK-8 
assay. Briefly, $4 \times 10^{3}$ cells were treated with $0.1 \%$ Tween- 80 (control) or DADS $(8 \mu \mathrm{M})$ at room temperature for 24,48 and $72 \mathrm{~h}$ after being transfected or not and then exposed to CCK-8 (10 $\mu \mathrm{l} /$ well) for $4 \mathrm{~h}$. The optical density (OD) values were measured at $490 \mathrm{~nm}$, and the inhibitory rate $=(1-$ OD value of experience group/OD value of control group) $\mathrm{x} 100 \%$. Each assay was performed with six replicates.

$R T$-semi-qPCR. The total RNA kit II was used to extract total RNA, according to the manufacturer's protocol, and complementary DNA was generated using the PrimeScript ${ }^{\mathrm{TM}}$ RT reagent kit. Each gene primer was synthesized by Invitrogen; Thermo Fisher Scientific, Inc., and their sequences were as follows: Cofilin 1 (120 bp) forward, 5'-CAAGAAGGCGGT GCTCT-3' and reverse, 5'-ACAAAGGTGGCGTAGGG-3'; Rac1 (100 bp) forward, 5'-CCCTATCCTATCCGCAAACA-3' and reverse, 5'-CGCACCTCAGGATACCACTT-3'; ROCK1 (113 bp) forward, 5'-AAAACCTTATTTGTGCCTTCC-3' and reverse, 5'-CGTTTCCCAAGCCCACT-3'; LIMK1 (138 bp) forward, 5'-GGGGCATCATCAAGAGCA-3' and reverse, 5'-GAGGACTAGGGTGGTTCAG-3'; and $\beta$-actin (367 bp) forward, 5'-ACACTGTGCCCATCTACGAGGGG-3' and reverse, 5'-ATGATGGAGTTGAAGGTAGTTTCGTGGAT-3'. The reaction conditions were as follows: $\beta$-actin, $94^{\circ} \mathrm{C}, 5 \mathrm{~min}$, 30 cycles $\left(94^{\circ} \mathrm{C}, 30 \mathrm{sec} ; 55.0^{\circ} \mathrm{C}, 30 \mathrm{sec} ; 72^{\circ} \mathrm{C}, 60 \mathrm{sec}\right), 72^{\circ} \mathrm{C}$, $5 \mathrm{~min}$; and for all other primers, $94^{\circ} \mathrm{C}, 5 \mathrm{~min} ; 30$ cycles $\left(94^{\circ} \mathrm{C}\right.$, $\left.30 \mathrm{sec} ; 54.5^{\circ} \mathrm{C}, 30 \mathrm{sec} ; 72^{\circ} \mathrm{C}, 60 \mathrm{sec}\right), 72^{\circ} \mathrm{C}, 5 \mathrm{~min}$. The semi-qPCR products were separated by $2 \%$ agarose gel electrophoresis. The Bio-Rad gel imaging system (Bio-Rad Laboratories, Inc.) and AlphaImager 2200 software (version 5.0; Alpha Innotech Corporation) were used to photograph, scan and calculate the relative OD values to demonstrate the gene expression abundances. $\beta$-actin expression was regarded as the internal control for determining the relative $\mathrm{OD}$ value.

Western blot analysis. HL-60 cell lines were treated with or without DADS $(8 \mu \mathrm{M})$ at $37^{\circ} \mathrm{C}$ for 12,24 and $48 \mathrm{~h}$ after being transfected or not. Total protein was then extracted using lysis buffer (catalog no. P0013; Beyotime Institute of Biotechnology) and $100 \mu \mathrm{g} / \mathrm{ml}$ PMSF (catalog no. ST505; Beyotime Institute of Biotechnology, China), and quantified with a BCA protein assay kit. Following electrophoresis, total protein (20-25 $\mu \mathrm{g} /$ lane) was separated by $12 \%$ SDS-PAGE and transferred onto a PVDF membrane. Primary antibodies, including anti-cofilin 1, anti-Rac1, anti-ROCK1, anti-LIMK1, anti-p-cofilin 1, anti-p-T508-LIMK1 and anti- $\beta$-actin, were used at 1:1,000, and incubated overnight at $4^{\circ} \mathrm{C}$. $\beta$-actin was employed as the loading control. The blots were washed three times for $5 \mathrm{~min}$ in TBS-T (containing 1\% Tween-20) and then incubated with peroxidase-conjugated secondary antibody $(1: 1,000)$ for $1 \mathrm{~h}$ at room temperature. Subsequently, the blots were washed three times for $10 \mathrm{~min}$ in TBS-T and then developed using a BeyoECL Plus Hypersensitive ECL Chemiluminescence kit. Alpha Imager 2200 (version 5.0; Alpha Innotech Corporation) was applied to evaluate the ODs of the band densities.

NBT reduction assay. HL-60 cells were maintained at a logarithmic growth rate and seeded at a density of $1 \times 10^{4}$ cells/well.
Following exposure to $8 \mu \mathrm{M}$ DADS at $37^{\circ} \mathrm{C}$ for $72 \mathrm{~h}$, cells were collected by centrifugation at $201 \mathrm{x} \mathrm{g}$ at room temperature for 5 min. Differentiation of HL-60 cells was assayed by adding $200 \mu \mathrm{l}$ NBT-TPA solution $(2 \mathrm{mg} / \mathrm{ml} \mathrm{NBT}$ and $0.24 \mathrm{mg} / \mathrm{ml}$ phorbol 12-myristate 13-acetate) in PBS to each well, incubation for $1 \mathrm{~h}$ at $37^{\circ} \mathrm{C}$, and suspension in $0.4 \mathrm{ml}$ cold $2 \mathrm{M} \mathrm{HCl}$. Subsequently, the formazan product was obtained by centrifugation at $700 \mathrm{x} \mathrm{g}$ at room temperature for $10 \mathrm{~min}$, and $200 \mu \mathrm{l}$ DMSO was added to dissolve the product. The absorbance of the solution was measured at $570 \mathrm{~nm}$.

Immunofluorescence ofCD11band CD33.Immunofluorescence analysis was performed to verify the subcellular localization of the general myeloid differentiation markers CD11b and CD33. HL-60 cells of each group were collected by centrifugation at $201 \mathrm{x} \mathrm{g}$ at room temperature for $5 \mathrm{~min}$. Cell suspension was added to cover the slides and dried at room temperature for $30 \mathrm{~min}$. Subsequently, the cells were fixed with $4 \%$ polyoxymethylene at room temperature for $30 \mathrm{~min}$, rinsed with $0.5 \%$ Triton X-100 in PBS for $15 \mathrm{~min}$, and then blocked with goat serum at room temperature for $30 \mathrm{~min}$. The CD11b (1:100) and CD33 (1:100) antibodies were incubated with the cells at $4^{\circ} \mathrm{C}$ overnight, followed by 5 -min washes in PBS three times. FITC-conjugated anti-rabbit IgG (catalog no. ab6717; Abcam; 1:1,000) at room temperature for $1 \mathrm{~h}$ was applied to assess CD11b and CD33. Images were obtained using an inverted fluorescence microscope (Olympus Corporation; magnification $\mathrm{x} 400$ ) and assessed with PearlScope software (version 1.0.0.1202).

Cell migration and invasion assays. Cell migration and invasion were assessed as previously described (17). Invasion assays were performed using Transwell assays. For the migration assay, cells were resuspended in serum-free RPMI-1640 medium and $100 \mu \mathrm{l}$ cell suspension $\left(1.0 \times 10^{6}\right.$ cells) was seeded into the upper chambers. RPMI-1640 (500 $\mu \mathrm{l})$ containing $10 \%$ FBS was added to the lower chambers. After transfected and untransfected cells were exposed to $8 \mu \mathrm{M}$ DADS at $37^{\circ} \mathrm{C}$ for $24 \mathrm{~h}$, hematoxylin was used to stain the cells at room temperature for $30 \mathrm{~min}$ on the lower surface of the filter. The cells were observed under an inverted microscope (Olympus Corporation; magnification, x400). The invasion assay protocol was the same as that of the migration assay except that the upper chambers were first coated with $1 \mathrm{mg} / \mathrm{ml}$ Matrigel. Invasion and migration rates are presented as ratios between DADS-treated and control group values.

Statistical analysis. All results are presented as the mean \pm standard deviation for three independent experiments. Comparisons between groups were made by one-way ANOVA with Fisher's Least Significant Difference for three groups and Tukey's test for $>3$ groups. Statistical analyses were performed using SPSS 13.0 software (SPSS, Inc.). $\mathrm{P}<0.05$ was considered to indicate a statistically significant difference.

\section{Results}

Effect of DADS on the differentiation, migration and invasion of HL-60 cells. Following incubation with $8 \mu \mathrm{M}$ DADS for different amounts of time, the proliferative ability of the 
human leukemic cell line HL-60 was assayed by cell proliferation analysis. Time-dependent cytotoxicity was determined after $8 \mu \mathrm{M}$ DADS treatment, and the OD value of the treated cells was $0.311 \pm 0.012$ at $24 \mathrm{~h}, 0.362 \pm 0.011$ at $48 \mathrm{~h}$ and $0.389 \pm 0.020$ at $72 \mathrm{~h}$, which were significantly lower than those of $0.540 \pm 0.009$ at $24 \mathrm{~h}, 0.691 \pm 0.014$ at $48 \mathrm{~h}$ and $0.791 \pm 0.019$ at $72 \mathrm{~h}$ in the untreated groups, respectively (Table I).

As presented in Table II, the NBT reduction ability of the untreated HL-60 cells was $0.419 \pm 0.010$ at $24 \mathrm{~h}, 0.446 \pm 0.016$ at $48 \mathrm{~h}$ and $0.504 \pm 0.026$ at $72 \mathrm{~h}$, and following treatment with $8 \mu \mathrm{M}$ DADS, the NBT reduction ability increased to $0.472 \pm 0.023$ at $24 \mathrm{~h}(\mathrm{P}=0.003), 0.536 \pm 0.006$ at $48 \mathrm{~h}(\mathrm{P}=0.001)$ and $0.620 \pm 0.013$ at $72 \mathrm{~h}(\mathrm{P}<0.001)$. Immunofluorescence experiments demonstrated that the expression of CD11b was markedly increased, while CD33 was markedly decreased, in the DADS-treated group compared with the untreated group (Fig. 1A). These results suggest that DADS can induce HL-60 cell differentiation.

Cells were exposed to $8 \mu \mathrm{M}$ DADS for 12 and $24 \mathrm{~h}$, and the effects of DADS on the migration and invasion of the leukemia HL-60 cell line were detected using Transwell experiments. As shown in Fig. 1B, the migration and invasion abilities of HL-60 cells were decreased by $8 \mu \mathrm{M}$ DADS treatment for 12 and $24 \mathrm{~h}$ compared with the control cells (migration at $12 \mathrm{~h}$, $\mathrm{P}=0.001$; migration at $24 \mathrm{~h}, \mathrm{P}<0.001$; invasion at $12 \mathrm{~h}, \mathrm{P}<0.001$; invasion at $24 \mathrm{~h}, \mathrm{P}<0.001)$. These data demonstrate that DADS can inhibit the migration and invasion of HL- 60 cells.

DADS downregulates Rac1/ROCK1/LIMK1/cofilin 1 signaling in HL-60 cells. Cofilin is reportedly associated with cell differentiation (16); however, no evidence of an association between the cofilin 1 pathway and leukemia cell differentiation exists. Therefore, the present investigated whether DADS affects the expression and activation of cofilin 1 in leukemia HL-60 cells. As presented in Fig. 2, following treatment with $8 \mu \mathrm{M}$ DADS for 12,24 and $48 \mathrm{~h}$, the mRNA and protein expression levels of cofilin 1 in HL-60 cells were significantly inhibited in a time-dependent manner. Similarly, the mRNA and protein expression levels of Rac1, Rock1 and LIMK1 were also significantly lower in HL-60 cells following exposure to DADS for 12,24 or $48 \mathrm{~h}$. Additionally, both the phosphorylated/total cofilin 1 protein ratio and the phosphorylated LIMK1/total LIMK1 protein ratio significantly decreased at $12 \mathrm{~h}, 24$ and $48 \mathrm{~h}$ after $8 \mu \mathrm{M}$ DADS treatment compared with the control.

Effect of DADS on the proliferation, differentiation and invasion of cofilin 1-silenced HL-60 cells. Cell proliferation analysis indicated that the proliferation inhibitory effect in cofilin 1-silenced cells (cofilin-miR) was significantly enhanced by treatment with $8 \mu \mathrm{M}$ DADS for 12, 24 and $48 \mathrm{~h}$ (Fig. 3A). However, $8 \mu \mathrm{M}$ DADS could significantly increase the NBT reduction ability in cofilin 1-miR cells, demonstrating that DADS cooperates with cofilin 1 silencing to affect the differentiation of HL-60 cells (Fig. 3B).

As shown in Fig. 3C, the numbers of cancer cells that migrated and invaded in the Transwell assay were significantly decreased following silencing of cofilin 1 compared with the control vector cells. Furthermore, DADS could significantly strengthen this inhibitory effect, suggesting that DADS
Table I. Effect of DADS on the proliferation ability of HL-60 cells.

\begin{tabular}{lccr}
\hline & \multicolumn{2}{c}{ Optical density at $490 \mathrm{~nm}$} & \\
\cline { 2 - 3 } Time, h & Untreated cells & DADS-treated cells & P-value \\
\hline 24 & $0.540 \pm 0.009$ & $0.311 \pm 0.012$ & 0.002 \\
48 & $0.691 \pm 0.014$ & $0.362 \pm 0.011$ & $<0.001$ \\
78 & $0.791 \pm 0.019$ & $0.000 \pm 0.000$ & $<0.001$ \\
\hline
\end{tabular}

DADS, diallyl disulfide.

Table II. Effect of DADS on the reduction ability of HL-60 cells.

NBT absorbance at $570 \mathrm{~nm}$

\begin{tabular}{lccr}
\cline { 2 - 3 } Time, h & Untreated cells & DADS-treated cells & P-value \\
\hline 24 & $0.419 \pm 0.010$ & $0.472 \pm 0.023$ & 0.003 \\
48 & $0.446 \pm 0.016$ & $0.536 \pm 0.006$ & 0.001 \\
72 & $0.504 \pm 0.026$ & $0.620 \pm 0.013$ & $<0.001$ \\
\hline
\end{tabular}

DADS, diallyl disulfide; NBT, nitroblue tetrazolium.

negatively effects the invasive ability of HL-60 cells via the downregulation of cofilin 1 expression.

Silencing of cofilin 1 enhanced CD11b expression and inhibited CD33 expression. In addition, the expression of CD11b increased, while the expression of CD33 decreased in the DADS-treated cofilin 1-silenced cells compared with the untreated cofilin 1-miR cells (Fig. 3D).

Effects of DADS on the Rac1-ROCK1-LIMK1 signaling pathway in cofilin 1-silenced HL-60 cells. To clarify the molecular mechanisms by which DADS induces differentiation and exerts inhibitory effects, the present study assessed whether silencing the cofilin 1 gene could interfere with the effects of DADS on the Rac1-ROCK1-LIMK1 signaling pathway. Silencing cofilin 1 significantly downregulated the protein expression of Rac1, ROCK1 and LIMK1 compared with control cells, and significantly increased the inhibitory effect of DADS on the protein expression of cofilin 1, Rac1, ROCK1 and LIMK1 compared with in the untreated cells (Fig. 4).

Effects of DADS on the proliferation, differentiation and invasion of cofilin 1-overexpressing HL-60 cells. Next, it was observed whether cofilin 1 overexpression influences the effects of DADS on proliferation, differentiation and invasion. As presented in Fig. 5A, following $24 \mathrm{~h}$ of DADS treatment, the proliferative abilities of the cells in the untransfected, negative control and high cofilin 1 expression groups were significantly lower compared with that in the untreated groups. The difference of the proliferative abilities between the cofilin-overexpression group and untransfected group 

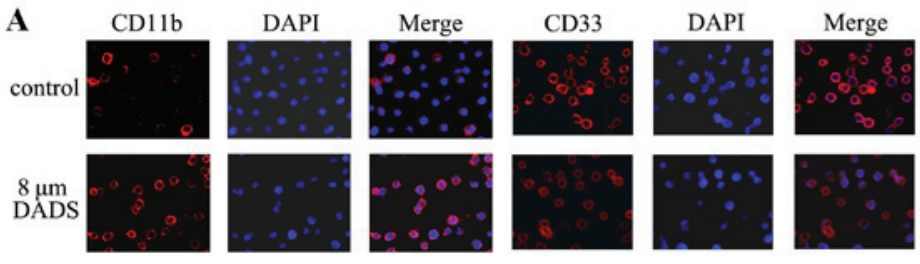

B
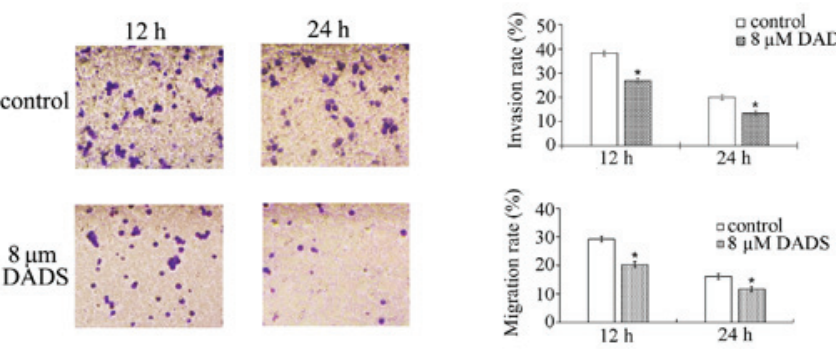

Figure 1. Effects of DADS on the differentiation induction, migration and invasion of the human leukemic cell line HL-60. (A) Expression of the cell surface differentiation markers CD11b and CD33 induced by DADS. Magnification, x200. HL-60 cells were exposed to $8 \mu \mathrm{M}$ DADS for $72 \mathrm{~h}$ and then fixed in $4 \%$ formaldehyde/PBS and permeabilized with $0.5 \%$ Triton X-100. CD11b and CD33 were detected by immunofluorescence (red, left panel). The DNA-intercalating dye DAPI was applied to recognize cell nuclei (blue, center panel). The right panel shows a merged image to highlight the nuclear pool of CD11b and CD33. (B) The effect of DADS on the migration and invasion of HL-60 cells. Magnification, x200. HL-60 cells were treated with $8 \mu$ M DADS for 12 and $24 \mathrm{~h}$. Cell migration and invasion were analyzed by Transwell migration and invasion assays, respectively. The migration rate is presented as the ratio of the mean migrated cell numbers between treated and untreated cells. The invasion rate is presented as the ratio of the mean cell numbers between treated and untreated cells. ${ }^{*} \mathrm{P}<0.05$ vs. the control. DADS, diallyl disulfide.
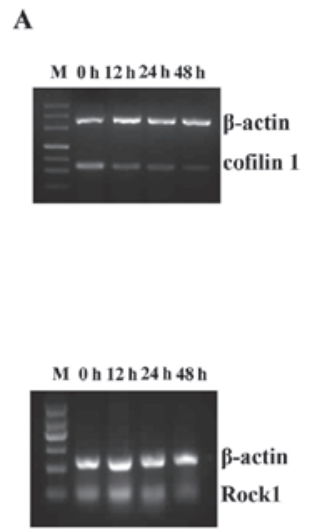

B
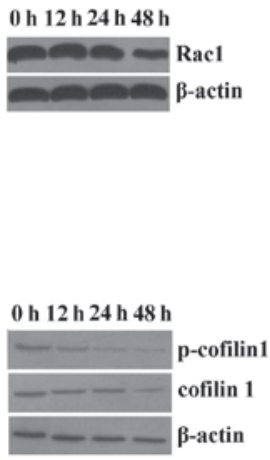
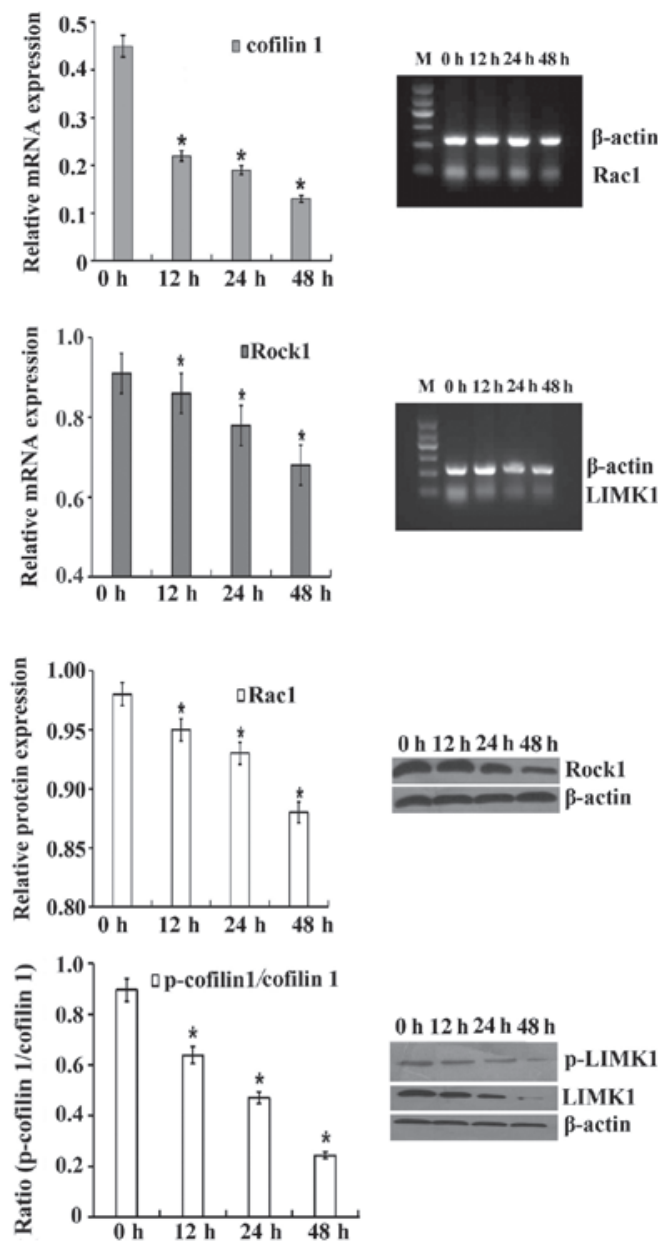
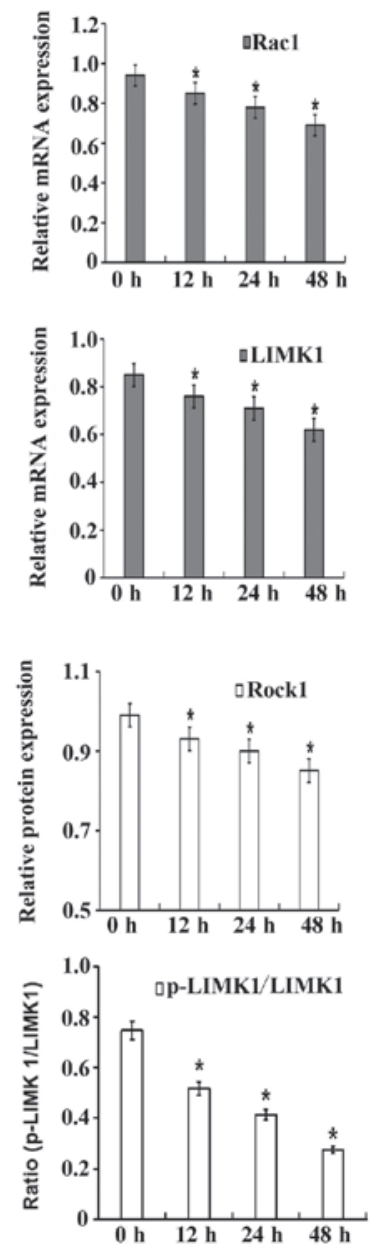

Figure 2. Inhibitory effect of DADS on Rac1/ROCK1/LIMK1/cofilin 1 signaling in HL-60 cells. The cells were treated with $8 \mu$ M DADS for the indicated amounts of time. (A) Reverse transcription-semi-quantitative PCR was performed to determine the mRNA expression levels of cofilin 1, Rac1, ROCK1 and LIMK1. $\beta$-actin was used as an internal control for normalization. (B) Western blotting was performed to determine cofilin 1, p-cofilin 1, Rac1, ROCK1, LIMK1 and p-LIMK1 protein levels. $\beta$-actin was used as a loading control. The relative fold changes in mRNA or protein levels were compared with $\beta$-actin controls. The results are presented as the mean \pm standard error of the mean from three independent experiments. ${ }^{*}<<0.05$ vs. the control ( $0 \mathrm{~h}$ group). DADS, diallyl disulfide; ROCK1, Rho-associated protein kinase 1; LIMK1, LIM domain kinase 1, p-, phosphorylated. 

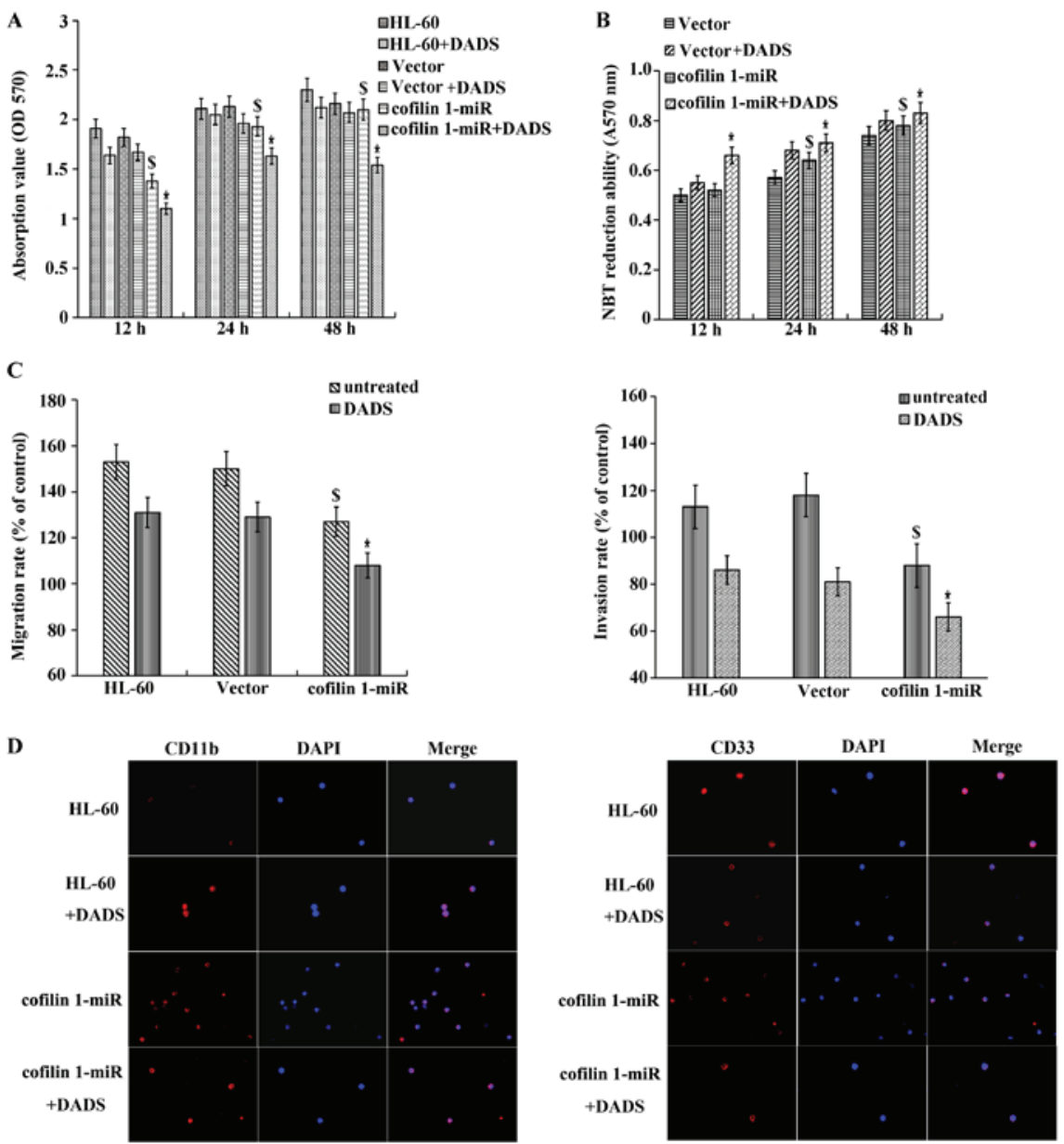

Figure 3. Effects of DADS and cofilin 1 miRNA expression plasmid transfection on the proliferation, differentiation and invasion of HL-60 cells. (A) Effect of DADS and cofilin 1 miRNA expression plasmid transfection on the viability of HL-60 cells. In total, $3 \times 10^{4}$ cells were treated with $8 \mu \mathrm{M}$ DADS for $48 \mathrm{~h}$, and the viable cells were analyzed for cell proliferation. (B) Effect of DADS and cofilin 1 miRNA expression plasmid transfection on NBT reduction in HL-60 cells. HL-60 cells were treated with $8 \mu \mathrm{M}$ DADS for 12,24 and $48 \mathrm{~h}$. The differentiation of HL-60 cells was identified by the decrease in NBT absorbance at $570 \mathrm{~nm}$. ${ }^{\$} \mathrm{P}<0.05$ vs. the untreated HL-60 group; ${ }^{*} \mathrm{P}<0.05$ vs. the untreated cofilin 1-miR group. (C) Effects of DADS and cofilin 1 miRNA expression plasmid transfection on the migration and invasion of HL-60 cells. Briefly, $8 \mu \mathrm{M}$ DADS was added to HL-60 cells and cells transfected with vector or a cofilin 1 miRNA expression plasmid for $24 \mathrm{~h}$. Cell migration and invasion were determined using Transwell migration and invasion assays, respectively. The migration rate is presented as the ratio of migrated cells between treated and untreated HL-60 cells. The invasion rate is presented as the ratio of the mean cell numbers between treated and untreated cells. ${ }^{*} \mathrm{P}<0.05$ vs. the untreated cofilin $1-\mathrm{miR}$ group. ${ }^{{ }^{\$}} \mathrm{P}<0.05$ vs. HL-60 cells (D) Expression of the cell surface differentiation markers CD11b and CD33 following DADS treatment and cofilin 1 miRNA expression plasmid transfection. Magnification, x200. CD11b and CD33 were identified by immunofluorescence (red, left panel). The DNA-intercalating dye DAPI was used to identify cell nuclei (blue, center panel). The right panel displays a merged image to highlight the nuclear pool of CD11b and CD33. Data are presented at the mean \pm standard error or the mean from three independent experiments. DADS, diallyl disulfide; miRNA, microRNA; NBT, nitroblue tetrazolium; OD, optical density; cofilin 1-miR, cells transfected with cofilin 1 miRNA.

was significant. The proliferation inhibition rate of DADS was $(37.42 \pm 3.67 \%)$ in the cofilin overexpression group, which was significantly lower than that in the untransfected group $(44.78 \pm 4.19 \%)$ and the vector-transfected group $(44.72 \pm 4.63 \%)$ (Table III). This indicates that cofilin 1 overexpression could reduce the inhibitory effect of DADS on the proliferation of HL-60 cells.

NBT experiments demonstrated that cofilin 1 overexpression could significantly inhibit the reducing ability of HL-60 cells. Furthermore, cofilin 1 overexpression significantly reduced the DADS-induced cell reducing ability, compared with the HL-60 cells treated with DADS $(\mathrm{P}=0.0133)$ and the vector group treated with DADS ( $\mathrm{P}=0.0049$; Fig. 5B). Transwell migration and invasion experiments indicated that overexpression of cofilin 1 significantly increased the migration and invasion abilities of HL-60 cells (migration, $\mathrm{P}=0.011$; invasion, $\mathrm{P}=0.005$ ) and significantly decreased the
DADS-induced migration and invasion inhibition (migration, $\mathrm{P}=0.004$; invasion, $\mathrm{P}=0.010$; Fig. 5C). Immunofluorescence experiments demonstrated that overexpression of cofilin 1 decreased the expression of CD11b, while the expression of CD33 had no obvious change, compared with the untreated HL-60 cells (Fig. 5D). CD11b expression was increased and CD33 expression was decreased in the DADS-treated cofilin 1-overexpressing cells compared with the cofilin 1-overexpressing cells without DADS treatment (Fig. 5D).

Effects of DADS on the Rac1-ROCK1-LIMK1 signaling pathway in cofilin 1-overexpressing HL-60 cells. After determining whether knockdown of cofilin 1 could enhance the suppressive effect of DADS on the Rac1-ROCK1-LIMK1 signaling pathway, it was investigated whether cofilin 1 overexpression serves a role in the effect of DADS on HL-60 cells. RT-semi-qPCR and western blot results demonstrated that 

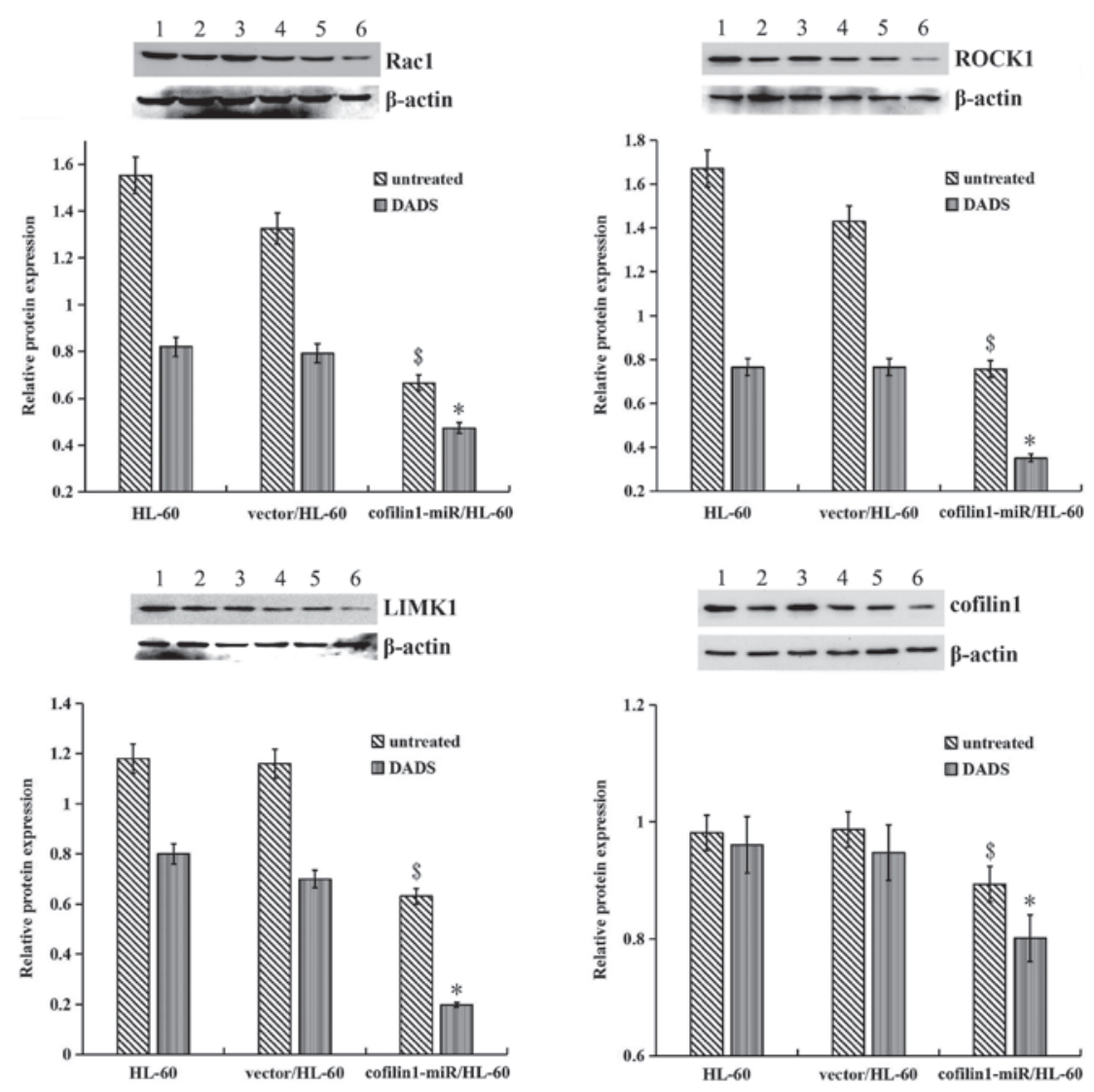

Figure 4. Effects of DADS on the Rac1-ROCK1-LIMK1 signaling pathway in cofilin 1 gene-silenced HL-60 cells. Western blotting was used to detect Rac1, ROCK1, LIMK1 and cofilin 1 protein levels. $\beta$-actin served as a loading control. The relative fold changes in protein levels compared with the $\beta$-actin control were analyzed. 1, untreated HL-60 cells; 2, HL-60 cells treated with DADS; 3, vector/HL-60 cells; 4, vector/HL-60 cells treated with DADS; 5 , cofilin 1-miR/HL-60 cells; and 6, cofilin 1-miR/HL-60 cells treated with DADS. Data are presented at the mean \pm standard error or the mean from three independent experiments. ${ }^{\$} \mathrm{P}<0.05$ vs. the untreated HL-60 group; ${ }^{*} \mathrm{P}<0.05$ vs. the untreated cofilin 1-silenced/HL-60 group. DADS, diallyl disulfide; ROCK1, Rho-associated protein kinase 1; LIMK1, LIM domain kinase 1; cofilin 1-miR, cells transfection with cofilin 1 miRNA overexpressing vector.

DADS significantly lowered the mRNA and protein expression levels of cofilin 1, Rac1, ROCK1 and LIMK1, and the ratios of p-cofilin/cofilin 1 and p-LIMK1/LIMK1 in cofilin 1-overexpressing cells compared with those without DADS treatment (Fig. 6).

\section{Discussion}

DADS, the main anticancer component in garlic, can suppress the proliferation of numerous types of cancer cells, such as leukemia, colon cancer and gastric cancer cells $(4,5,18,19)$. It has been suggested that DADS induces the differentiation of the human gastric cancer cell line MGC803 (20) and the leukemia cell line HL-60 (5). Previously, we demonstrated that $8 \mu \mathrm{M}$ DADS could induce the differentiation of human leukemia HL-60 cells to a granulocytic lineage, which is similar to the effects of $1 \mu \mathrm{M}$ all-trans retinoic acid (ATRA) (5). In the present study, DADS could inhibit the proliferation, migration and invasion of HL-60 cells and induce their differentiation, similar to ATRA. These results suggest that DADS may be a potential compound for inducing differentiation. However, the precise molecular mechanisms underlying these anti-metastatic effects of DADS are not completely understood.

In a previous study, DADS was shown to regulate the expression of cofilin 1 (5). The present study verified that DADS gradually decreased the mRNA and protein expression, as well as the phosphorylation of cofilin 1 in HL-60 cells in a time-dependent manner. Cofilin-1, an actin depolymerizing factor (ADF)/cofilin superfamily member, has been shown to be highly expressed in a number of cancer types and is associated with proliferation, migration, invasion, differentiation, metastasis and poor prognosis $(16,21)$. The expression level of cofilin and its subcellular distribution play important roles in the high migratory ability of tumor cells (22). The high expression of cofilin-1 in malignant cells can enhance the speed of cell migration, while silencing cofilin-1 can delay cancer cell metastasis (15). Cofilin-1 can depolymerize actin filaments by binding directly to actin and make the actin filaments turn over quickly $(23,24)$, thus controlling cell movement, which serves an important role in the proliferation and migration of tumor cells (11). Cofilin 1 is involved in tumor invasion, metastasis and prognosis by regulating actin reorganization and pseudopodia formation; sustained activation of cofilin 1 promotes the formation and migration of filamentous pseudopodia in prostate cancer cells and enhances the metastatic ability of prostate cancer in vivo (25). O-(link)-N-acetylation glycosylation modification of the cofilin 1 Ser108 site facilitates its correct localization in the invasive pseudopod and promotes the invasion of cancer cells (26). The high expression and phosphorylation of cofilin 1 serves an important role in the occurrence and development of cancer (27). The suppression of cofilin-1 and the translocation of cofilin 1 
Table III. Effect of DADS on the proliferation ability of HL-60 cells, vector-transfected cells and cofilin 1-transfected cells.

Optical density value

\begin{tabular}{lcccc} 
Group & Untreated cells & DADS-treated cells & P-value & Inhibitory rate, \% \\
\hline Untransfected HL-60 cells & $0.585 \pm 0.0019$ & $0.323 \pm 0.018^{\mathrm{a}}$ & 0.0069 & $44.78 \pm 4.19$ \\
Vector-transfected HL-60 cells & $0.587 \pm 0.021$ & $0.324 \pm 0.017^{\mathrm{b}}$ & 0.0083 & $44.72 \pm 4.63$ \\
Cofilin 1-transfected HL60 cells & $0.652 \pm 0.020^{\mathrm{c}}$ & $0.408 \pm 0.024^{\mathrm{d}, \mathrm{e}}$ & 0.0011 & $37.42 \pm 3.67$ \\
\hline
\end{tabular}

${ }^{\text {aP }}<0.01$ vs. the untransfected HL- 60 cells. ${ }^{\mathrm{b}} \mathrm{P}<0.01$ vs. the vector-transfected HL- 60 cells. ${ }^{\mathrm{c}} \mathrm{P}<0.01$ vs. the untransfected HL- 60 cells and the vector-transfected HL-60 cells. ${ }^{\mathrm{d}} \mathrm{P}<0.01$ vs. the the Cofilin 1 -transfected HL-60 cells. ${ }^{e} \mathrm{P}<0.001$ vs. the DADS-treated untransfected HL-60 cells and the DADS-treated vector-transfected HL-60 cells. DADS, diallyl disulfide.
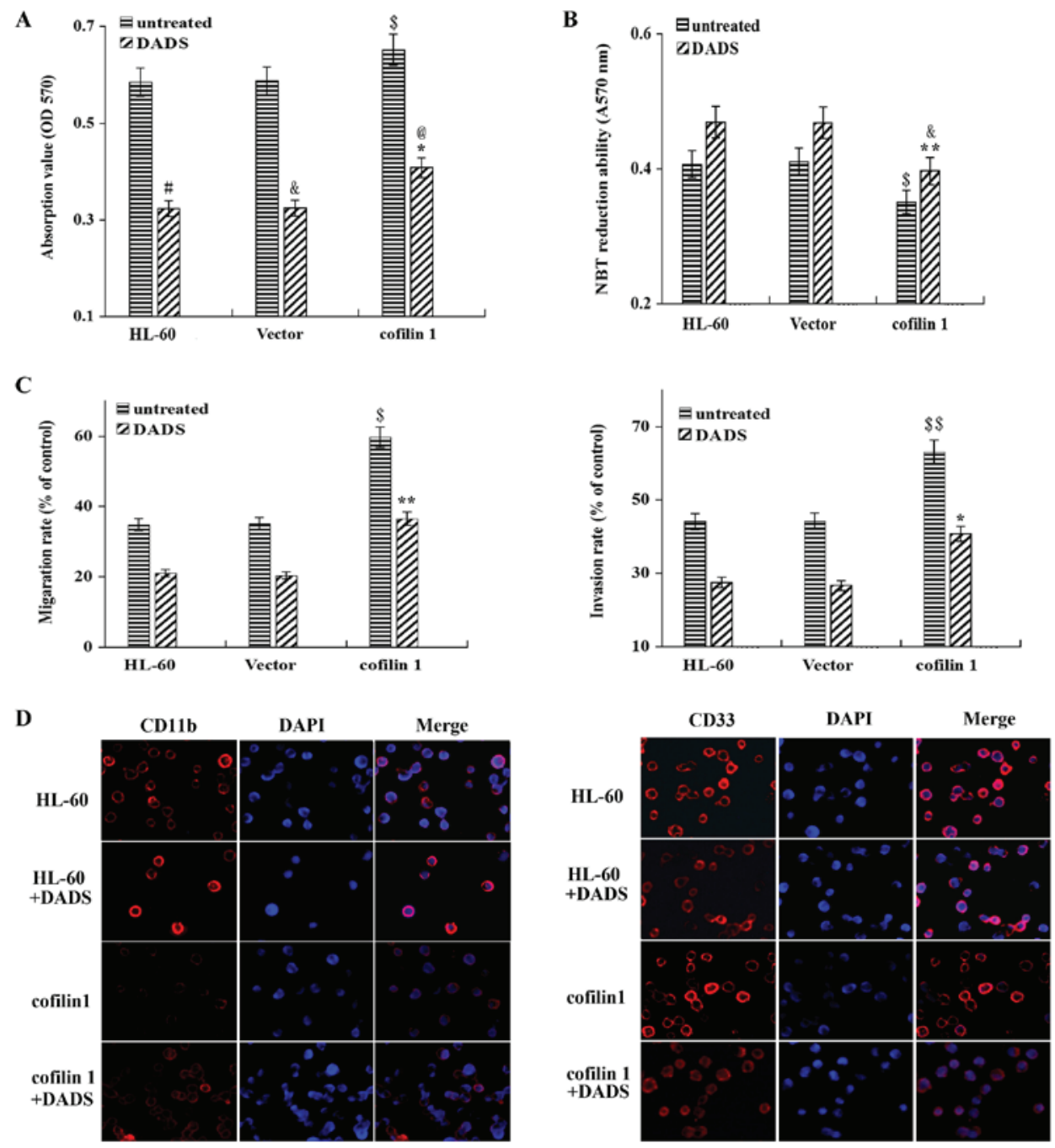

Figure 5. Effect of DADS on the proliferation, differentiation and invasion of cofilin 1-transfected HL-60 cells. (A) Effect of DADS on the viability of HL-60 cells, vector-transfected cells and cofilin 1-transfected cells. In total, $3 \times 10^{4}$ cells were treated with $8 \mu \mathrm{M}$ DADS for $48 \mathrm{~h}$, and the viable cells were analyzed for cell proliferation. ${ }^{~} \mathrm{P}<0.01$ vs. the untreated HL-60 group; ${ }^{\circledR} \mathrm{P}<0.01$ vs. the untreated vector group; ${ }^{\$} \mathrm{P}<0.001$ vs. the untreated HL- 60 group and the untreated vector-transfected group; ${ }^{*} \mathrm{P}<0.01$ vs. the untreated cofilin 1 group; ${ }^{\circledR} \mathrm{P}<0.001$ vs. the untransfected cells treated with DADS and the vector-transfected cells treated with DADS. (B) Effect of DADS on NBT reduction in HL-60 cells, vector-transfected cells and cofilin 1-transfected cells. HL-60 cells were treated with $8 \mu \mathrm{M}$ DADS for $48 \mathrm{~h}$. The differentiation of HL-60 cells was determined by the decrease in NBT absorbance at $570 \mathrm{~nm} .{ }^{\$} \mathrm{P}<0.05 \mathrm{vs}$. the untreated HL-60 group; ${ }^{\text {P }}<0.05$ vs. the HL-60 group with DADS treatment; ${ }^{* *} \mathrm{P}<0.01$ vs. the vector group with DADS treatment. (C) Effects of DADS on the migration and invasion of HL-60 cells. Briefly, $8 \mu$ M DADS was added to HL-60 cells, vector-transfected cells and cofilin 1-transfected cells for $24 \mathrm{~h}$. Cell migration and invasion were examined using Transwell migration and invasion assays, respectively. The migration rate was calculated as the ratio of migrated cells between DADS-treated and untreated HL-60 cells. The invasion rate was estimated by the ratio of mean cell numbers between treated and untreated cells. ${ }^{\$} \mathrm{P}<0.05$, ${ }^{\$ \$} \mathrm{P}<0.01$ vs. the untreated HL-60 group; ${ }^{*} \mathrm{P}<0.05,{ }^{* *} \mathrm{P}<0.01$ vs. the untreated cofilin 1 group. (D) Expression of the cell surface differentiation markers CD11b and CD33 after DADS treatment and cofilin 1 transfection. Magnification, x200. CD11b and CD33 were identified by immunofluorescence (red, left panel). The DNA-intercalating dye DAPI was used to identify cell nuclei (blue, center panel). The right panel displays a merged image to highlight the nuclear pool of CD11b and CD33. DADS, diallyl disulfide; OD, optical density; NBT, nitroblue tetrazolium. 

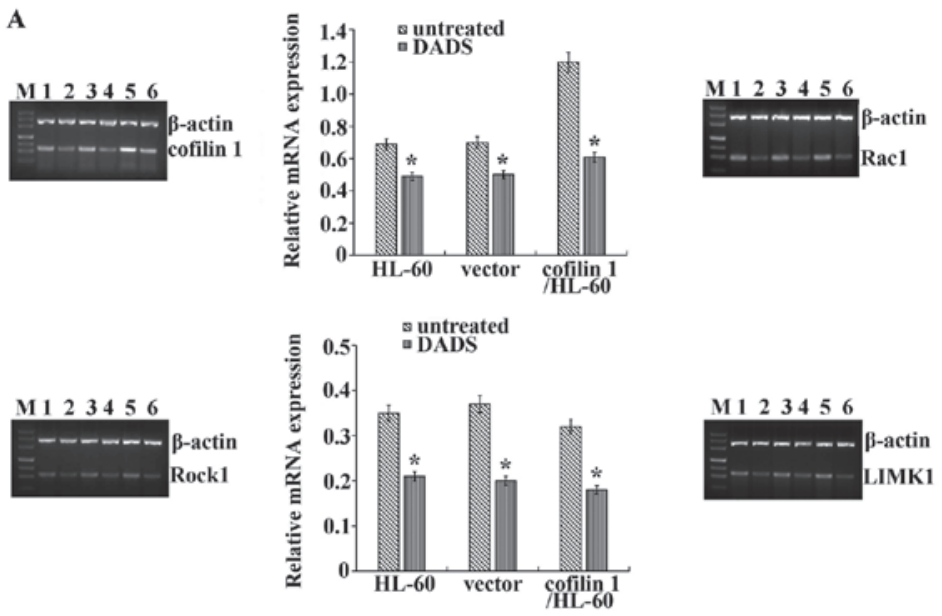

B
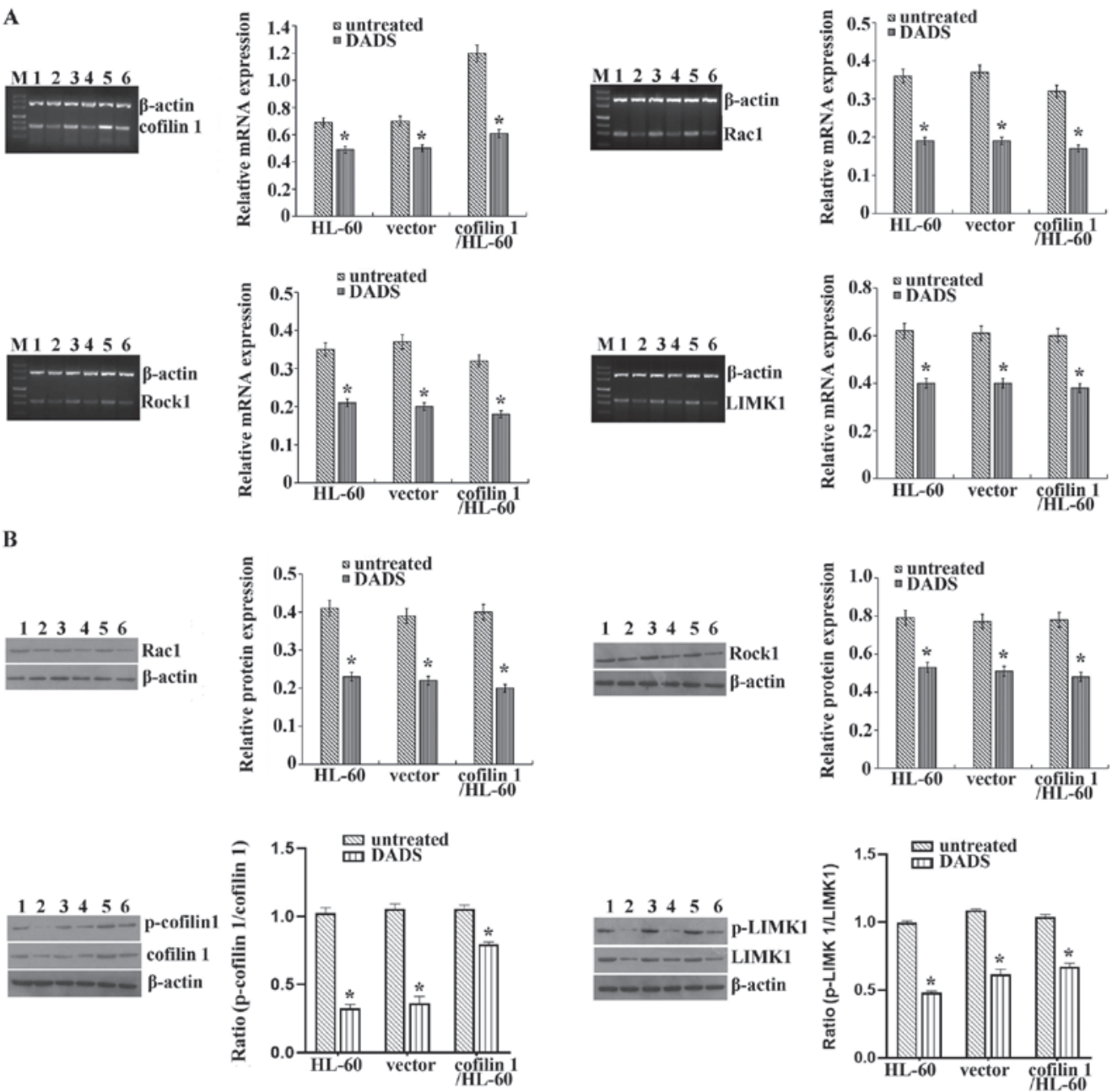

Figure 6. Effects of DADS on the Rac1-ROCK1-LIMK1 signaling pathway in cofilin 1-transfected HL-60 cells. (A) Reverse transcription-semi-quantitative PCR was used to determine the mRNA expression levels of Rac1, ROCK1, LIMK1 and cofilin 1. $\beta$-actin was used as an internal control for normalization. (B) Western blotting was employed to detect cofilin 1, p-cofilin 1, Rac1, ROCK1, LIMK1 and p-LIMK1 protein levels. $\beta$-actin was regarded as a loading control. The relative fold changes in mRNA or protein levels were compared with $\beta$-actin controls. M, Maker; 1 , untreated HL-60 cells; 2 , HL-60 cells treated with DADS; 3, vector/HL-60 cells; 4, vector/HL-60 cells treated with DADS; 5, cofilin 1/HL-60 cells; and 6, cofilin 1/HL-60 cells treated with DADS. Data are presented at the mean \pm standard error or the mean from three independent experiments. "P $<0.05$ vs. the untreated HL-60 group. DADS, diallyl disulfide; ROCK1, Rho-associated protein kinase 1; LIMK1, LIM domain kinase 1; p-, phosphorylated.

from the cytoplasm to mitochondria can induce cancer cell apoptosis $(28,29)$. High cofilin-1 expression is associated with cisplatin chemoresistance in carcinomas (30). Serum cofilin-1 protein expression is increased in carcinomas and may be a promising serum biomarker for prognosis $(31,32)$. Notably, the present study found that silencing cofilin 1 by miRNA could markedly promote the DADS-induced differentiation and inhibitory effect on the proliferation and invasion of HL-60 cells. However, overexpression of cofilin 1 significantly suppressed these effects induced by DADS. These data provide evidence that cofilin 1 is involved in DADS-induced differentiation and growth inhibition in human leukemia HL-60 cells.

Our previous study demonstrated that DADS reduces LIMK1 expression in gastric cancer MGC-803 cells (19) and inhibits the migration and invasion capabilities of colon cancer SW480 cells via downregulation of the Rac1-ROCK1/PAK1-LIMK1-ADF/cofilin signaling pathway (33). Thereafter, it was suspected that the Rac1-ROCK1/LIMK1 pathway is involved in regulating cofilin expression and activation, and consequently, differentiation

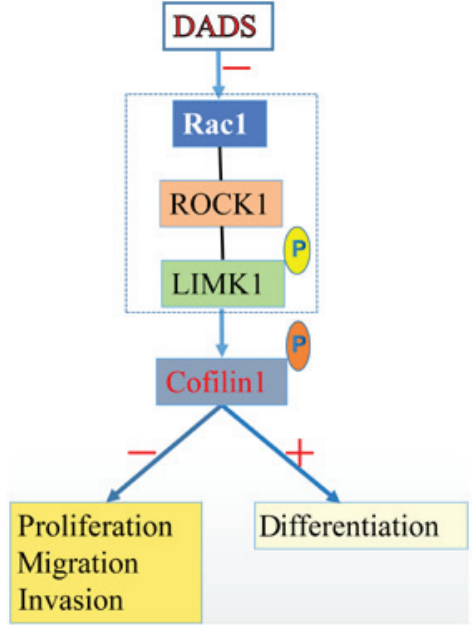

Figure 7. Role of DADS in leukemia cells. DADS negatively regulates the Rac1-ROCK1-LIMK1 signaling pathway, decreases cofilin 1 expression and suppresses its phosphorylation, which leads to inhibition of proliferation, migration and invasion, and differentiation induction in leukemia HL-60 cells. DADS, diallyl disulfide; ROCK1, Rho-associated protein kinase 1; LIMK1, LIM domain kinase 1. 
induction in HL-60 cells. In the present study, it was identified that DADS can suppress the mRNA and protein expression of Rac1, ROCK1 and LIMK1, as well as the phosphorylation of LIMK1 in HL-60 cells in a time-dependent manner. Silencing cofilin 1 by miRNA decreased the protein expression of Rac1, ROCK1 and LIMK1, and increased the inhibitory effect of DADS on cofilin 1 mRNA expression and the protein expression of cofilin 1, Rac1, ROCK1 and LIMK1. By contrast, high expression of cofilin 1 reduced the inhibitory effect of DADS on these molecules. Cofilin is regulated by various upstream signals, predominantly RhoGTP enzyme family members, which are involved in tumor occurrence and development. RhoGTP enzyme family members, including Rho, Rac and $\mathrm{Cdc} 42$, are closely associated with cytoskeleton reorganization and serve an important role in cell motility, migration and invasion (34). The degree of Rac signaling plays a crucial role in the balance between differentiation and proliferation; cellular Racl is indispensable for differentiation (35), and RhoA/ROCK signaling plays an important role in differentiation induction (36). The activation of Rho and Racl can phosphorylate the kinase ROCK and activate LIMK1, as Rac can activate LIMK1, which induces cofilin 1 phosphorylation at Ser3 and thus regulates the actin cytoskeleton; this process indicates the formation of the Rac1-ROCK1/LIMK1-cofilin signaling pathway by regulating tumor cell migration and invasion $(37,38)$. The inhibition of the ROCK/PTEN pathway and cofilin-1 expression is involved in the induction of cancer cell apoptosis (39). Cofilin cuts fibrous type F-actin and accelerates free actin polymerization, and the phosphorylated state of cofilin 1 is regulated by LIMK1 (40). In addition, LIMK1-mediated cofilin phosphorylation has important effects on tumorigenesis, matrix adhesion, transfer speed and direction of tumor cell invasion (41). In the present study, the protein expression levels of Rac1, ROCK1 and LIMK1 increased in cofilin 1-silenced HL-60 cells, while the expressions of these molecules were not significantly altered in cofilin 1-overexpressing HL-60 cells. This indicates that there may be a signal interaction centered on cofilin 1, which participates in other signal pathways, such as the Rac1-WAVE2-Arp2/3 pathway (42), when activated, and this conclusion needs to be confirmed by further research in the future. However, DADS can regulate the expression of Rac1, Rock1, LIMK1 and cofilin 1, whether cofilin 1 is overexpressed or silenced.

In summary, DADS could decrease cofilin 1 expression and suppress its phosphorylation by negatively regulating the Rac1-ROCK1-LIMK1 signaling pathway and lead to the inhibited proliferation and induced differentiation of leukemia HL-60 cells (Fig. 7). The present study helps to identify targets for inducing leukemia differentiation and provides a theoretical basis for leukemia differentiation induction therapy.

\section{Acknowledgements}

Not applicable.

\section{Funding}

This study was performed using equipment purchased with funding from the construct program of the key discipline in Hunan Province, China (Basic Medicine Sciences at University of South China) [grant no. (2011)76]. This work was supported by the National Natural Science Foundation of China (grant nos. 81100375, 31201027 and 81400117), the Patency Foundation of Innovation Platform of Hunan Provincial University of China (grant no. 11K057) and the Natural Science Foundation of Hunan Province (grant no. 2015JJ4042).

\section{Availability of data and materials}

The datasets generated and/or analyzed during the present study are available from the corresponding author upon reasonable request.

\section{Authors' contributions}

HL and QS conceived the idea and designed the study. JH, XJ, YL and YJ performed all of the experiments. FL and HX analyzed the data. HT, XZ and LY performed the statistical analysis. HL wrote the manuscript. All authors have reviewed the manuscript and read and approved the final manuscript.

\section{Ethics approval and consent to participate}

Not applicable.

\section{Patient consent for publication}

Not applicable.

\section{Competing interests}

The authors declare that they have no competing interests.

\section{References}

1. Mahmud H, ter Elst A, Scherpen FJG, de Boer TM, Kampen KR, de Haas V, Guryev V, Peppelenbosch MM, Kornblau SM and de Bont ESJM: Peptide microarray of pediatric acute myeloid leukemia is related to relapse and reveals involvement of DNA damage response and repair. Oncotarget 10: 4679-4690, 2019.

2. Surveillance, Epidemiology, and End Results (SEER) Program, SEER*Stat Database: Incidence - SEER 9 Regs Research Data, Nov 2017 Sub (1973-2015) - Linked To County Attributes - Total U.S., 1969-2016 Counties. National Cancer Institute, DCCPS, Surveillance Research Program, released April 2018, based on the November 2017 submission. https://www.seer.cancer.gov.

3. Yi L and Su Q: Molecular mechanisms for the anti-cancer effects of diallyl disulfide. Food Chem Toxicol 57: 362-370, 2013.

4. Zhao J, Huang WG, He J, Tan H, Liao QJ and Su Q: Diallyl disulfide suppresses growth of HL-60 cell through increasing histone acetylation and p21WAF1 expression in vivo and in vitro. Acta Pharmacol Sin 27: 1459-1466, 2006.

5. Ling H, He J, Tan H, Yi L, Liu F, Ji X, Wu Y, Hu H, Zeng X, Ai X, et al: Identification of potential targets for differentiation in human leukemia cells induced by diallyl disulfide. Int J Oncol 50: 697-707, 2017.

6. Nishida E, Maekawa S and Sakai H: Cofilin, a protein in porcine brain that binds to actin filaments and inhibits their interactions with myosin and tropomyosin. Biochemistry 23: 5307-5313, 1984.

7. Van Troys M, Huyck L, Leyman S, Dhaese S, Vandekerkhove J and Ampe C: Ins and outs of $\mathrm{ADF} /$ cofilin activity and regulation. Eur J Cell Biol 87: 649-667, 2008.

8. Verdoni AM, Aoyama N, Ikeda A and Ikeda S: Effect of destrin mutations on the gene expression profile in vivo. Physiol Genomics 34: 9-21, 2008 . 
9. Bernstein BW and Bamburg JR: ADF/cofilin: A functional node in cell biology. Trends Cell Biol 20: 187-195, 2010.

10. Ostrowska Z and Moraczewska J: Cofilin - a protein controlling dynamics of actin filaments. Postepy Hig Med Dosw 71: 339-351, 2017.

11. Kapoor S: Cofilin-1 overexpression and its role in tumor growth and progression in systemic malignancies. Int J Radiat Biol 90: $113,2014$.

12. Li D, Wang H, Song H, Xu H, Zhao B, Wu C, Hu J, Wu T, Xie D, Zhao J, et al: The microRNAs miR-200b-3p and miR-429-5p target the LIMK1/CFL1 pathway to inhibit growth and motility of breast cancer cells. Oncotarget 8: 85276-85289, 2017.

13. Wang H, Gu H, Feng J, Qian Y, Yang L, Jin F, Wang X, Chen J, Shi Y, Lu S, et al: Celastrus orbiculatus extract suppresses the epithelial-mesenchymal transition by mediating cytoskeleton rearrangement via inhibition of the Cofilin 1 signaling pathway in human gastric cancer. Oncol Lett 14: 2926-2932, 2017.

14. Huang TY, DerMardirossian C and Bokoch GM: Cofilin phosphatases and regulation of actin dynamics. Curr Opin Cell Biol 18: 26-31, 2006.

15. Schiapparelli P, Guerrero-Cazares H, Magaña-Maldonado R, Hamilla SM, Ganaha S, Goulin Lippi Fernandes E, Huang CH, Aranda-Espinoza H, Devreotes P and Quinones-Hinojosa A: NKCC1 Regulates Migration Ability of Glioblastoma Cells by Modulation of Actin Dynamics and Interacting with Cofilin. EBioMedicine 21: 94-103, 2017.

16. Zhou J, Wang Y, Fei J and Zhang W: Expression of cofilin 1 is positively correlated with the differentiation of human epithelial ovarian cancer. Oncol Lett 4: 1187-1190, 2012.

17. Su B, Su J, He H, Wu Y, Xia H, Zeng X, Dai W, Ai X, Ling H, Jiang $\mathrm{H}$, et al: Identification of potential targets for diallyl disulfide in human gastric cancer MGC-803 cells using proteomics approaches. Oncol Rep 33: 2484-2494, 2015.

18. Huang YS, Xie N, Su Q, Su J, Huang C and Liao QJ: Diallyl disulfide inhibits the proliferation of HT-29 human colon cance cells by inducing differentially expressed genes. Mol Med Rep 4: 553-559, 2011.

19. Su B, Su J, Zeng Y, Liu F, Xia H, Ma YH, Zhou ZG, Zhang S, Yang BM, Wu YH, et al: Diallyl disulfide suppresses epithelial-mesenchymal transition, invasion and proliferation by downregulation of LIMK1 in gastric cancer. Oncotarget 7: 10498-10512, 2016.

20. Ling H, Zhang LY, Su Q, Song Y, Luo ZY, Zhou XT, Zeng X, $\mathrm{He} \mathrm{J}$, Tan $\mathrm{H}$ and Yuan JP: Erk is involved in the differentiation induced by diallyl disulfide in the human gastric cancer cell line MGC803. Cell Mol Biol Lett 11: 408-423, 2006.

21. Wang F, Wu D, Fu H, He F, Xu C, Zhou J, Li D, Li G, Xu J Wu Q, et al: Cofilin 1 promotes bladder cancer and is regulated by TCF7L2. Oncotarget 8: 92043-92054, 2017.

22. Nowak D, Mazur AJ, Popow-Woźniak A, Radwańska A, Mannherz HG and Malicka-Błaszkiewicz M: Subcellular distribution and expression of cofilin and ezrin in human colon adenocarcinoma cell lines with different metastatic potential. Eur J Histochem 54: e14, 2010

23. Ma M, Zhou L, Guo X, Lv Z, Yu Y, Ding C, Zhang P, Bi Y, Xie J, Wang L, et al: Decreased cofilin1 expression is important for compaction during early mouse embryo development. Biochim Biophys Acta 1793: 1804-1810, 2009.

24. Pfaendtner J, De La Cruz EM and Voth GA: Actin filament remodeling by actin depolymerization factor/cofilin. Proc Nat Acad Sci USA 107: 7299-7304, 2010.

25. Collazo J, Zhu B, Larkin S, Martin SK, Pu H, Horbinski C, Koochekpour S and Kyprianou N: Cofilin drives cell-invasive and metastatic responses to TGF- $\beta$ in prostate cancer. Cancer Res 74: 2362-2373, 2014.

26. Huang X, Pan Q, Sun D, Chen W, Shen A, Huang M, Ding J and Geng M: O-GlcNAcylation of cofilin promotes breast cancer cell invasion. J Biol Chem 288: 36418-36425, 2013.
27. Chung H, Kim B, Jung SH, Won KJ, Jiang X, Lee CK, Lim SD, Yang SK, Song KH and Kim HS: Does phosphorylation of cofilin affect the progression of human bladder cancer? BMC Cancer 13: 45, 2013.

28. Tang Q, Ji Q, Tang Y, Chen T, Pan G, Hu S, Bao Y, Peng W, Yin P, Shimizu H, et al: Mitochondrial translocation of cofilin-1 promotes apoptosis of gastric cancer BGC-823 cells induced by ursolic acid. Tumour Biol 35: 2451-2459, 2014.

29. Xiao P, Ma T, Zhou C, Xu Y, Liu Y and Zhang H: Anticancer effect of docetaxel induces apoptosis of prostate cancer via the cofilin-1 and paxillin signaling pathway. Mol Med Rep 13: 4079-4084, 2016.

30. Becker M, De Bastiani MA, Müller CB, Markoski MM, Castro MA and Klamt F: High cofilin-1 levels correlate with cisplatin resistance in lung adenocarcinomas. Tumour Biol 35: $1233-1238,2014$

31. Satoh M, Takano S, Sogawa K, Noda K, Yoshitomi H, Ishibashi M, Mogushi K, Takizawa H, Otsuka M, Shimizu H, et al: Immune-complex level of cofilin-1 in sera is associated with cancer progression and poor prognosis in pancreatic cancer. Cancer Sci 108: 795-803, 2017.

32. Zheng Y, Fang Y, Li S and Zheng B: Detection of plasma cofilin protein for diagnosis of lung cancer. Nan Fang Yi Ke Da Xue Xue Bao 33: 1551-1553, 2013 (In Chinese).

33. Zhou Y, Su J, Shi L, Liao Q and Su Q: DADS downregulates the Rac1-ROCK1/PAK1-LIMK1-ADF/cofilin signaling pathway, inhibiting cell migration and invasion. Oncol Rep 29: 605-612, 2013.

34. Borensztajn K, Peppelenbosch MP and Spek CA: Coagulation Factor Xa inhibits cancer cell migration via LIMK1-mediated cofilin inactivation. Thromb Res 125: e323-e328, 2010.

35. Niit M, Arulanandam R, Cass J, Geletu M, Hoskin V, Côté G, Gunning P, Elliott B and Raptis L: Regulation of HC11 mouse breast epithelial cell differentiation by the E-cadherin/Rac axis. Exp Cell Res 361: 112-125, 2017.

36. Yang L, Dai F, Tang L, Le Y and Yao W: Macrophage differentiation induced by PMA is mediated by activation of RhoA/ROCK signaling. J Toxicol Sci 42: 763-771, 2017.

37. Aggelou H, Chadla P, Nikou S, Karteri S, Maroulis I, Kalofonos HP, Papadaki H and Bravou V: LIMK/cofilin pathway and Slingshot are implicated in human colorectal cancer progression and chemoresistance. Virchows Arch 472: 727-737, 2018.

38. Prunier C, Prudent R, Kapur R, Sadoul K and Lafanechère L: LIM kinases: Cofilin and beyond. Oncotarget 8: 41749-41763, 2017.

39. Gai WT, Yu DP, Wang XS and Wang PT: Anti-cancer effect of ursolic acid activates apoptosis through ROCK/PTEN mediated mitochondrial translocation of cofilin-1 in prostate cancer. Oncol Lett 12: 2880-2885, 2016.

40. Ishaq M, Lin BR, Bosche M, Zheng X, Yang J, Huang D, Lempicki RA, Aguilera-Gutierrez A and Natarajan V: LIM kinase 1 - dependent cofilin 1 pathway and actin dynamics mediate nuclear retinoid receptor function in $\mathrm{T}$ lymphocytes. BMC Mol Biol 12: 41, 2011

41. Kaji N, Muramoto A and Mizuno K: LIM kinase-mediated cofilin phosphorylation during mitosis is required for precise spindle positioning. J Biol Chem 283: 4983-4992, 2008

42. Zhou T, Wang CH, Yan H, Zhang R, Zhao JB, Qian CF, Xiao H and Liu HY: Inhibition of the Rac1-WAVE2-Arp $2 / 3$ signaling pathway promotes radiosensitivity via downregulation of cofilin-1 in U251 human glioma cells. Mol Med Rep 13: 4414-4420, 2016. 